\title{
PEMETAAN POTENSI PRODUKSI PADI SAWAH (Oryza sativa L) DENGAN MENGGUNAKAN MODEL SIMULASI TANAMAN DI KABUPATEN MINAHASA SELATAN
}

\author{
Verby N.D. Rumintjap \\ Johanes F. X. Rogi \\ Deddie Tooy
}

\begin{abstract}
South Minahasa Regency is one of regencies in the province of North Sulawesi, which had agro-climatic conditions suitable for the growth of rice plants. To determine the growth and development of the rice crop in the South Minahasa District, with various agro-climatic conditions can be simulated models of rice plants. This study aims to determine the potential for rice production in South Minahasa Regency and mapping potential for rice production in South Minahasa Regency. This research was conducted through the collection of climate data (solar radiation, air temperature, air humidity, while irradiation and precipitation) and the data on latitude and longitude coordinates. Implementation using simulation models of rice plants Rice Shierary V.2.1 to determine the potential of rice production and rice production potential mapping in South Minahasa district to use Photo Satellite Imagery processed through ArcView 3.3 software. Research results show the potential of rice production is the village Popontolen 6.11 ton ha-1, village Pakuweru 5.73 ton ha-1, and the Village Karowa 9.00 ton ha-1, the highest production potential are among the sites that Karowa Village 9.00 ton ha-1 is due to have the most ideal temperature for growth and development of paddy rice at an average of $23.12{ }^{\circ} \mathrm{C}$, and the average rainfall is $293.50 \mathrm{~mm}$ and $103.42 \mathrm{~mm}$ evapotranspiration. Data from the study indicate the potential for a higher yield than the data Provitas paddy rice official South Minahasa District of 2010-2014. This shows that the achievement of rice production in the district south minahasa not optimal. Hopefully the results of this study be input for agencies involved in this case the Department of Agriculture and Livestock South Minahasa regency in optimizing rice production with activities touching the supporting factors of production such as the provision of improved seed, fertilizer use impartial, repair dams and irrigation networks as well as the use of tools and agricultural machinery so as to increase farmers' income.
\end{abstract}

Keywords: Rice, Potential Production, Shierary Rice V.2.1, South Minahasa

\begin{abstract}
ABSTRAK
Kabupaten Minahasa Selatan merupakan salah satu kabupaten di provinsi Sulawesi Utara yang memiliki kondisi agroklimat yang cocok untuk pertumbuhan tanaman padi. Untuk mengetahui pertumbuhan dan perkembangan tanaman padi di Kabupaten Minahasa Selatan, dengan berbagai kondisi agroklimat dapat digunakan model simulasi tanaman padi. Penelitian ini bertujuan untuk menentukan potensi produksi padi sawah di Kabupaten Minahasa Selatan dan pemetaan potensi produksi padi sawah di Kabupaten Minahasa Selatan. Penelitian ini dilaksanakan melalui pengumpulan data iklim (radiasi matahari, suhu udara, kelembaban udara, lama penyinaran dan curah hujan) serta data koordinat lintang dan bujur. Pelaksanaan dengan menggunakan model simulasi tanaman padi Shierary Rice V.2.1 untuk mengetahui potensi produksi padi sawah serta pemetaan potensi produksi padi sawah di Kabupaten Minahasa Selatan dengan menggunakan Foto Citra Satelit yang diolah melalui perangkat lunak Arcview 3.3. Hasil Penelitian menunjukan Potensi hasil produksi padi sawah yaitu Desa Popontolen 6,11 ton ha ${ }^{-1}$, Desa Pakuweru 5,73 ton $\mathrm{ha}^{-1}$, dan Desa Karowa 9,00 ton ha ${ }^{-1}$, potensi produksi tertinggi berada pada lokasi penelitian Desa Karowa yaitu 9,00 ton $\mathrm{ha}^{-1}$ disebabkan memiliki suhu yang paling ideal untuk pertumbuhan dan perkembangan padi sawah yaitu rata-rata $23,12{ }^{\circ} \mathrm{C}$, serta curah hujan rata-rata $293,50 \mathrm{~mm}$ dan evapotranspirasi 103,42 mm. Data hasil penelitian menunjukan potensi hasil yang lebih tinggi daripada data Provitas resmi padi sawah Kabupaten Minahasa Selatan dari tahun 2010-2014. Hal ini menunjukan bahwa pencapaian produksi padi sawah di kabupaten minahasa selatan belum optimal. Semoga hasil penelitian ini menjadi masukan bagi instansi terkait dalam hal ini Dinas Pertanian dan Peternakan Kabupaten Minahasa Selatan dalam mengoptimalkan produksi padi sawah dengan kegiatan menyentuh faktor-faktor pendukung produksi seperti penyediaan benih unggul, penggunaan pupuk yang berimbang, perbaikan bendungan dan jaringan irigasi serta penggunaan alat dan mesin pertanian sehingga dapat meningkatkan pendapatan petani.
\end{abstract}

Kata Kunci: Padi Sawah, Potensi Produksi, Shierary Rice V.2.1, Minahasa Selatan 


\section{PENDAHULUAN}

\section{Latar Belakang}

Tanaman Padi sawah merupakan komoditas pangan yang penting bagi manusia, karena merupakan salah satu sumber makanan pokok sebagian besar penduduk dunia. Kebutuhan akan beras cenderung meningkat dari tahun ke tahun seiring dengan bertambahnya jumlah penduduk dunia termasuk Indonesia.

Pembangunan pertanian yang berlandaskan pada Rencana Pembangunan Jangka Menengah Nasional (RPJMN) ketiga (20152019), dimana RPJMN tersebut sebagai penjabaran dari Visi, Program Aksi Presiden/Wakil Presiden Jokowi dan Jusuf Kalla serta berpedoman pada Rencana Pembangunan Jangka Panjang Nasional 20052025. Visi pembangunan dalam RPJM 20152019 adalah "Terwujudnya Indonesia yang Berdaulat, Mandiri dan Berkepribadian Berlandaskan Gotong Royong”. Visi tersebut dijabarkan menjadi Tujuh Misi serta Sembilan Agenda Prioritas (NAWA CITA). Dalam aspek ideologi, PANCASILA 1 JUNI 1945 dan TRISAKTI menjadi ideologi bangsa sebagai penggerak, pemersatu perjuangan, dan sebagai bintang pengarah. Berdasarkan Sembilan Agenda Prioritas (Nawa Cita) tersebut, maka agenda prioritas di bidang pertanian terdiri dari dua hal, yaitu (1) Peningkatan Agroindustri, dan (2) Peningkatan Kedaulatan Pangan. (Renstra Kementerian Pertanian RI, 2014-2019).

Salah satu upaya dalam mewujudkan kedaulatan pangan yaitu melalui peningkatan ketahanan pangan. Untuk tetap meningkatkan dan memperkuat kedaulatan pangan, sasaran utama prioritas nasional bidang pangan pertanian periode 2015-2019 adalah : tercapainya peningkatan ketersediaan pangan yang bersumber dari produksi dalam negeri. Produksi padi diutamakan ditingkatkan dalam rangka swasembada agar kemandirian dapat dijaga.

Produksi padi antara tahun 2010-2014 meningkat rata-rata sebesar $1,63 \%$ tahun $^{-1}$. Pemicu peningkatan produksi padi diantaranya karena peningkatan luas panen seluas 540 ribu ha dan produktivitas sebesar 1,20 ku/ha. Pertumbuhan luas panen padi di Jawa hanya sekitar 0,20 \%/tahun sedangkan di luar Jawa sekitar 1,76 \%/tahun (Renstra Kementrian Pertanian RI, 2014-2019).

Kabupaten Minahasa Selatan merupakan salah satu kabupaten di Provinsi Sulawesi Utara yang memiliki kondisi agroklimat yang cocok untuk pertumbuhan tanaman padi, dengan lahan yang luas serta berpotensi untuk dikembangkan. Menurut data dari Dinas Pertanian dan Peternakan Kab. Minahasa Selatan Tahun 2014 memiliki lahan sawah potensial seluas 5.391 Ha. Berbagai upaya dilakukan untuk menjadikan Kabupaten Minahasa Selatan sebagai lumbung beras untuk Provinsi Sulawesi Utara antara lain perluasan lahan pertanian, Optimasi lahan, Rehabilitasi jaringan irigasi dan penggunaan bibit unggul.

Untuk mengetahui secara akurat proses pertumbuhan dan perkembangan tanaman padi di Kabupaten Minahasa Selatan, sehingga Kabupaten ini dapat dikembangkan menjadi sentra produksi padi, dengan berbagai kondisi agroklimat maka dapat digunakan model simulasi tanaman padi. Model simulasi digunakan untuk menjelaskan proses dalam suatu sistem pertanaman pada berbagai tingkat kompleksitas dan bersifat fleksibel di dalam sintesis informasi karena dapat menerangkan keluaran sistem atas masukan sistem yang berupa faktor-faktor lingkungan dan penerapan teknik budidaya (Rogi, 2002).

\section{Botani Tanaman Padi Sawah}

Berdasarkan klasifikasinya tanaman padi sawah termasuk famili gramineae sub famili oryzidae dan genus oryzae (Suparyono dan Setyano, 1997). Padi termasuk tanaman semusim, batangnya beruas-ruas yang didalamnya berongga (kosong), tingginya 11,5 meter. Pada tiap-tiap buku batang tumbuh daun yang berbentuk pita dan pelepah, pelepah membulat hampir sekeliling batang (Daradjat dkk, 2009).

\section{Tanaman Padi dan Lingkungan Tumbuhnya}

Tanaman padi menghendaki lingkungan yang cocok untuk pertumbuhannya. Faktorfaktor lingkungan yang mendukung selain air dan tanah juga faktor iklim yang meliputi 
curah hujan, temperatur, radiasi, kelembaban dan kecepatan angin.

Tanaman padi merupakan tanaman daerah tropis tetapi dapat juga tumbuh di daerah sub tropis dengan suhu rata-rata 20$25^{\circ} \mathrm{C}$ dan suhu minimum $10^{\circ} \mathrm{C}$, tanaman padi sawah juga membutuhkan curah hujan minimum 1400-1800 mm setahun dan untuk produksi yang baik harus mendapatkan penyinaran matahari yang cukup (Anonim, 1990).

Kebutuhan tanaman padi sawah akan air tergantung pada siklus hidupnya misalnya untuk keperluan pengolahan tanah diberikan 1,45 liter $\mathrm{Ha}^{-1}$ detik ${ }^{-1}$ selama enam minggu kemudian setelah tanam diberikan 1 liter $\mathrm{Ha}^{-1}$ detik $^{-1}$ selama 12 minggu dan pada akhir pertumbuhannya $( \pm$ dua minggu sebelum matang fisiologis) tidak diberikan air lagi. Padi sawah ditanam pada tanah lempung yang berat dengan kedalaman sekitar $30 \mathrm{~cm}$ di bawah permukaan tanah dengan $\mathrm{PH}$ yang netral (Hardjono dkk, 1981).

\section{Model Simulasi Tanaman Padi}

Model simulasi tanaman padi ini dikembangkan berdasarkan model Shierary-rice (Handoko, 1996) digunakan untuk keperluan pemantauan padi di Indonesia dengan beberapa pertimbangan :

1. Model ini mempunyai resolusi harian yang menjelaskan proses interaksi anatara perkembangan dana pertumbuhan tanaman padi dengan unsur-unsur cuaca serta beberapa sifat fisik dan kimia tanah.

2. Model ini telah divalidasi pada skala kebun percobaan (pertumbuhan, perkembangan, neraca air, neraca nitrogen dan produktivitas) dan kabupaten (produktivitas) dari berbagai kondisi cuaca.

Model Shierary rice terdiri dari 4 (empat) sub model yang saling berinteraksi yaitu :

\section{Sub model perkembangan tanaman}

Sub model perkembangan tanaman menjelaskan serta menduga waktu kejadian fase-fase perkembangan tanaman padi yang terdiri dari semai, tanam, tunas maximum, anthesis (penyerbukan) dan panen. Metode yang digunakan ialah konsep thermal unit, sehingga sub model ini memerlukan input berupa suhu udara harian (Handoko, 1996)

\section{Sub model pertumbuhan tanaman}

Sub-model pertumbuhan tanaman menduga pertumbuhan masing-masing organ tanaman (akar, batang, daun, dan biji padi) mulai semai sampai panen. Pertumbuhan dihitung dari energi radiasi surya yang diintersepsi tajuk tanaman padi. Energi radiasi surya yang diintersepsi merupakan fungsi indeks luas daun (LAI), sedangkan biomassa yang konversi ditentukan oleh ketersediaan air serta status nitrogen daun (Handoko, 1996).

\section{Sub-Model Neraca Air}

Submodel ini mensimulasi aliran air dari hujan yang jatuh ke permukaan tajuk tanaman, sebagian diintersepsi dan sisanya jatuh ke permukaan tanah atau genangan air. Air yang sampai di permukaan akan masuk ke dalam tanah sebagai infiltrasi, menambah tinggi genangan air atau mengalir sebagai limpasan permukaan. Sebagian air akan diuapkan langsung ke atmosfer dan sebagian akan diserap akar tanaman sebagai transpirasi. Model ini ditujukan untuk padi sawah dengan lapisan bajak sehingga aliran ke bawah sebagai drainase dianggap tidak terjadi (Handoko, 1996).

\section{Sub-Model Neraca Nitrogen}

Sub-model ini mensimulasi dinamika nitrogen dalam tanah dan tanaman. Untuk pertumbuhan tanaman, sumber nitrogen berasal dari nitrogen mineral $\left(\mathrm{NH}_{4}{ }^{+}\right.$dan $\left.\mathrm{NO}_{3}{ }^{-}\right)$ hasil mineralisasi atau pemupukan. Laju pengambil-an nitrogen oleh akar tanaman dihitung berdasarkan aliran massa (mass flow) melalui transpirasi serta melalui pengambilan aktif oleh akar tanaman (active uptake). Jumlah nitrogen yang diambil tanaman juga ditentukan oleh kebutuhan nitrogen (nitrogen demand) masing-masing organ (batang, daun, akar, biji). Transformasi nitrogen dalam tanah 
dari bentuk organik menjadi mineral didekati dari fungsi suhu, kandungan air tanah dan $\mathrm{pH}$. Nitrogen yang diserap tanaman selanjutnya dialokasikan ke akar, batang daun dan biji sesuai dengan kebutuhan nitrogen (nitrogen demand), pertumbuhan serta perkembangan tanaman (Handoko, 1996).

\section{Sistem Informasi Geografis Arcview}

Arcview merupakan sebuah software GIS yang memiliki tampilan sederhana manarik, interaktif namum memiliki tingkat kemudahan yang cukup tinggi dan kemampuan analisis yang sangat baik. Kemampuan analisis tersebut diantaranya kemampuan untuk mendapatkan informasi dari obyek yang dipilih, membuat zone buffer suatu objek seperti jalan atau sungai, membuat operasi overlay terhadap poligon, penggunaan operator-operator query basis data relasional, penggunaan fungsi-fungsi statistik dan sebagainya (Budianto, 2005).

\section{Rumusan Masalah}

Berdasarkan latar belakang, maka yang menjadi permasalahan dalam penelitian ini adalah: (1) Bagaimana menduga potensi produksi padi sawah yang digunakan untuk perencanaan dalam usaha pengembangannya di Kabupaten Minahasa Selatan; (2) Bagaimana hubungan faktor-faktor yang mempengaruhi pertumbuhan dan perkembangan padi sawah di Kabupaten Minahasa Selatan.

\section{Tujuan}

Adapun yang menjadi tujuan dari penelitian ini adalah (1) Menentukan potensi produksi padi sawah dengan menggunakan Model Simulasi Tanaman Shierary Rice V.2.1 di Kabupaten Minahasa Selatan; (2). Pemetaan potensi produksi padi sawah di Kabupaten Minahasa Selatan.

\section{Manfaat Penulisan}

Hasil penelitian ini diharapkan dapat memberikan masukan bagi instansi terkait dalam perencanaan sebagai pendukung dalam pengambilan keputusan untuk pengembangan padi sawah di Kabupaten Minahasa Selatan.

\section{METODOLOGI PENELITIAN}

\section{Waktu Dan Tempat Penelitian}

Penelitian dilaksanakan selama dua bulan terhitung akhir Juni s/d akhir Agustus 2015 di lokasi penelitian yang meliputi Desa Popontolen Kecamatan Tumpaan, Desa Pakuweru Kecamatan Tenga dan Desa Karowa Kecamatan Tompaso Baru serta Dinas Pertanian dan Peternakan Kabupaten Minahasa Selatan dan melakukan Run Model di Laboratorium Modeling Ekosistem Jurusan Budidaya Pertanian Fakultas Pertanian Universitas Sam Ratulangi Manado.

\section{Alat dan Bahan \\ Bahan yang digunakan yaitu :}

1. Data iklim untuk lima tahun terakhir (20102014) yang terdiri dari data curah hujan, suhu udara, kelembaban udara, tekanan udara, angin dan radiasi matahari.

2. Data produksi padi sawah lima Tahun (20102014) Dinas Pertanian dan Peternakan Kabupaten Minahasa Selatan.

3. Data waktu tanam.

4. Data tanah (kapasitas lapang dan titik layu permanen)

5. Teknik budidaya (verietas, pemupukan dan jenis irigasi)

6. Foto Citra Satelit Desa Popontolen Kecamatan Tumpaan, Desa Pakuweru Kecamatan Tenga dan Desa Karowa Kecamatan Tompaso Baru.

7. Data teknik budidaya padi sawah oleh petani di tiga sampel lokasi penelitian.

Alat yang digunakan yaitu :

Seperangkat PC yang dilengkapi dengan perangkat lunak Model Simulasi Tanaman Padi Sawah (Shierary Rice V.2.1) dan Arcview 3.3 dan GPS (Global Positioning System).

\section{Prosedur Kerja}

Penelitian ini dilaksanakan melalui beberapa tahap yaitu :

Tahap I.

Pengambilan tititk koordinat (lintang dan bujur) tiga sampel lokasi penelitian yang mewakili tujuh kecamatan dengan potensi sawah utama yaitu Desa Popontolen Kecamatan Tumpaan, Desa Pakuweru Kecamatan Tenga dan Desa Karowa Kecamatan Tompaso Baru 
dengan menggunakan GPS (Global Positioning System).

Tahap II.

Pengumpulan data iklim (radiasi matahari, suhu udara, kelembapan udara, lama penyinaran, dan curah hujan) dengan menggunakan model pembangkit data cuaca harian, penentuan data tanah (kapasitas lapang dan titik layu permanen), waktu tanam, teknik budidaya (jenis varietas, irigasi dan pemupukan) di tiga sampel lokasi penelitian. Tahap III.

Penentuan potensi produksi padi sawah dengan menggunakan model simulasi tanaman padi sawah Shierary Rice V.2.1

Tahap IV.

Pemetaan potensi hasil padi sawah di Kabupaten Minahasa Selatan

\section{HASIL DAN PEMBAHASAN}

\section{Kondisi Geografis Kabupaten Minahasa Selatan}

Letak geografis Kabupaten Minahasa Selatan berada pada posisi tengah jazirah Provinsi Sulawesi Utara, yang secara administratif terletak di sebelah selatan Kabupaten Minahasa (induk), dengan batasbatas wilayah sebagai berikut:

Utara : Berbatasan dengan Kabupaten Minahasa.

Timur : Berbatasan dengan Kabupaten Minahasa Tenggara.

Selatan : Berbatasan dengan Kabupaten Bolaang Mongondow dan Kabupaten Bolaang Mongondow Timur.

Barat : Berbatasan dengan Laut Sulawesi.

Luas wilayah Kabupaten Minahasa Selatan adalah $\mathbf{1 . 4 8 4 , 4 7} \mathbf{k m}^{\mathbf{2}}$ dan masih terdapat kawasan yang masih terjadi genangan dengan topografi wilayah berupa bukit-bukit/pegunungan, sebagian kecil dataran rendah, bergelombang dan memiliki sungai-sungai besar dengan posisi dari daerah pantai sampai ketinggian 1.500 meter dari permukaan laut.
Jumlah kecamatan di Kabupaten Minahasa selatan 17 kecamatan dengan 167 desa dan 10 kelurahan. Penduduk berjumlah 241.862 jiwa, terdiri atas 124.247 laki-laki dan 117.615 perempuan, dan 80.615 KK. Dari data yang ada, jumlah penduduk berjenis kelamin laki-laki lebih banyak yaitu sebesar 51,37 \% dari jumlah penduduk berjenis kelamin perempuan sebesar $48,63 \%$.

Luas lahan sawah di Kabupaten Minahasa Selatan sebanyak 5.391 Ha (Data Dinas Pertanian dan Peternakan Kab. Minahasa Selatan, Tahun 2014), dengan laju pertumbuhan penduduk yang makin meningkat setiap tahun kebutuhan akan konsumsi pangan semakin meningkat juga.

Luas Panen dan produksi padi sawah di Kabupaten Minahasa Selatan tahun 2010 - 2014 dapat dilihat pada Tabel 1.

Tabel 1. Data Produksi Padi Sawah di Kabupaten Minahasa Selatan Tahun 2010-2014

\begin{tabular}{cccc}
\hline Tahun & $\begin{array}{c}\text { Luas } \\
\text { Panen } \\
\text { (Ha) }\end{array}$ & $\begin{array}{c}\text { Provitas } \\
\left(\text { Ton Ha }^{-1} \text { ) }\right.\end{array}$ & $\begin{array}{c}\text { Produksi } \\
\text { (Ton) }\end{array}$ \\
\hline 2010 & 13.147 & 5,166 & 67.917 \\
2011 & 13.013 & 5,208 & 67.771 \\
2012 & 13.101 & 5,228 & 68.496 \\
2013 & 13.495 & 5,358 & 72.306 \\
2014 & 12,884 & 5.335 & 68,740 \\
\hline Sumber & : & Dinas Pertanian dan Peternakan \\
& \multicolumn{4}{l}{ Kabupaten Minahasa Selatan }
\end{tabular}

\section{Analisis Sistem}

\section{Analisis Kebutuhan Masukan}

Kebutuhan data masukan untuk model simulasi ini adalah data iklim di Kabupaten Minahasa Selatan berupa data curah hujan, lama penyinaran matahari, radiasi ditambah dengan data lintang dan bujur lokasi sampel penelitian, jenis varietas (IR-64), pemakaian pupuk $\mathrm{N}(250 \mathrm{~kg})$, jenis sawah irigasi, waktu tanam (32 Julian Date), kapasitas lapang (30 $\%$ ) dan titik layu permanen (15\%). Data iklim Kabupaten Minahasa Selatan didapat dari model pembangkit data cuaca harian, sementara data lintang dan bujur sampel lokasi penelitian diambil dilokasi yaitu di 
Desa Popontolen Kecamatan Tumpaan ( $1^{0}{ }^{16}$ ' $22.2577^{\prime}$ N, $124^{0} 37^{\prime} 18.4891$ E), Desa Pakuweru Kecamatan Tenga ( $1^{0} 11$ ' 4.1512" $\mathrm{N}, 124^{0} 25^{\prime} 53.0882$ E) dan Desa Karowa Kecamatan Tompaso Baru ( $0^{0} 54$ ' 3.0252" N, $124^{0} 29$ ' 15.4164" E) dengan menggunakan GPS. Pemilihan tiga desa sebagai keterwakilan tiga daerah besar potensi sawah di Kabupaten Minahasa Selatan yaitu daerah Tumpaan dan Tatapaan, daerah Tenga dan Sinonsayang dan daerah Ranoyapo, Tompaso Baru dan Maesaan. Data iklim dan data lintang dan bujur lokasi penelitian dapat dilihat pada Tabel 2 .

\section{Analisis Kebutuhan Keluaran (Output)}

Kebutuhan keluaran dari sistem ini ialah informasi potensi hasil padi dengan menggunakan model simulasi tanaman padi sawah Shierary Rice V.2.1. Berikut ini akan ditampilkan hasil run pendugaan produksi padi sawah dengan menggunakan Shierary Rice V.2.1 untuk Desa Popontolen Kecamatan Tumpaan, Desa Pakuweru Kecamatan Tenga dan Desa Karowa Kecamatan Tompaso Baru.

Dengan Masukan data iklim seperti pada Tabel 2 serta menggunakan verietas IR64, Penggunaan Pupuk N $250 \mathrm{Kg}$, lahan sawah irigasi, masa tanam 32 julian date (1 Februari), maka didapatkan potensi hasil untuk Desa Popontolen Kecamatan Tumpaan sebesar 6,11 ton ha $^{-1}$ dengan masa tanam 128 hari, Desa Pakuweru Kecamatan Tenga sebesar 5,73 ton $\mathrm{ha}^{-1}$ dengan masa tanam 114 hari, dan Desa Karowa Kecamatan Tompaso Baru sebesar 9,00 ton ha $^{-1}$ dengan masa tanam 142 hari.

Berikut ini ditampilkan potensi hasil padi sawah di tiga lokasi penelitian yaitu Desa Popontolen Kecamatan Tumpaan, Desa Pakuweru Kecamatan Tenga dan Desa Karowa Kecamatan Tompaso Baru hasil run menggunana Shierary Rice V.2.1 seperti terlihat pada Tabel 3 dan Gambar 1.

Dari Tabel 3 dan Gambar 1 terlihat bahwa potensi hasil tertinggi berada di Desa Karowa Kecamatan Tompaso Baru 9,00 ton ha $^{-1}$, kemudian Desa Popontolen Kecamatan Tumpaan 6,11 ton $\mathrm{ha}^{-1}$, dan terendah di Desa
Pakuweru Kecamatan Tenga 5,73 ton $\mathrm{ha}^{-1}$. Untuk melihat kenapa terjadi demikian, terlebih dahulu akan dibandingkan potensi hasil, dengan data iklim berupa curah hujan, suhu maksimum, evapotranspirasi $(\mathrm{mm})$, radiasi matahari, dan intensitas cahaya matahari (jam) di tiga lokasi penelitian seperti terlihat pada Tabel 4-8.

Dari Tabel 4 terlihat bahwa potensi hasil ( ton ha ${ }^{-1}$ ) tertinggi diperoleh pada lokasi penelitian dengan tingkat curah hujan ( $\mathrm{mm}$ ) paling tinggi. Curah hujan sangat mempengaruhi produksi padi sawah, karena kebutuhan air bagi tanaman padi sangat dibutuhkan sehingga diperluhkan irigasi untuk suplai air apabila tidak tanaman akan mengalami stress air. Suhu udara juga sangat berpengaruh pada pertumbuhan dan perkembangan tanaman padi sawah, dari data penelitian terlihat bahwa suhu udara di desa karowa paling rendah tetapi potensi hasil paling tinggi.

Dari Tabel 5 terlihat kisaran suhu maksimum rata-rata di lokasi penelitian yaitu $23,12{ }^{\circ} \mathrm{C}-28,89{ }^{\circ} \mathrm{C}$. Menurut Lakitan, (1994) tanaman padi dapat hidup baik didaerah yang berhawa panas dan banyak mengandung uap air. Curah hujan yang baik rata-rata $200 \mathrm{~mm}$ per bulan atau lebih, dengan distribusi selama 4 bulan, curah hujan yang dikehendaki per tahun sekitar 1500- $2000 \mathrm{~mm}$. Suhu yang baik untuk pertumbuhan tanaman padi $23{ }^{\circ} \mathrm{C}$. Tinggi tempat yang cocok untuk tanaman padi berkisar antara $0-1500 \mathrm{~m} \mathrm{dpl}$. Peng et.al., 1994, lebih tingginya potensi hasil padi di daerah sub tropik dibandingkan dengan didaerah tropik disebabkan oleh lebih rendahnya suhu udara didaerah sub tropik sehingga fase tumbuhnya terutama fase pengisian gabah lebih lama.

Menurut Supijanto (2012), pada kondisi keterssediaan air yang cukup, suhu yang tinggi memiliki dampak yang kecil terhadap produksi padi kerena adanya proses penguapan evapotransparasi. Hasil penelitian ini mendukung teori dimana terlihat bahwa potensi hasil teringgi yaitu di Desa Karowa Kecamatan Tompaso Baru memiliki nilai evapotranspirasi terendah yaitu 103,42 mm. 
Tabel 2. Data Iklim Lokasi Penelitian

\begin{tabular}{clccccc}
\hline No & Desa & \multicolumn{5}{c}{ Data Iklim rata-rata } \\
\cline { 3 - 6 } & & Ch $(\mathrm{mm})$ & $\begin{array}{c}\text { Solar } \\
\left(\mathrm{MJ} \mathrm{m}^{-2} \text { hari }^{-1}\right)\end{array}$ & Tmax (oC) & $\begin{array}{c}\text { RH } \\
(\%)\end{array}$ & ETP (mm) \\
\hline 1 & Popontolen & 284,08 & 22,78 & 27,93 & 83,61 & 120,47 \\
2 & Pakuweru & 270,57 & 22,80 & 28,89 & 84,29 & 121,93 \\
3 & Karowa & 293,50 & 22,66 & 23,12 & 90,70 & 103,42 \\
\hline
\end{tabular}

Menurut Kartasapoetra (1993) kebutuhan tanaman akan radiasi matahari berbeda-beda menurut jenis dan fase pertumbuhannya. Radiasi matahri berperan dalam proses fotosintesis yang menjadi bahan utama dalam pertumbuhan dan produksi tanaman pangan serta mempercepat proses pertumbuhan dan pembuahan. Dari Tabel 7 terlihat bahwa radiasi matahari $\left(\mathrm{MJ} \mathrm{m}^{-2}\right.$ hari $\left.^{-1}\right)$

Tabel 3. Data Potensi Hasil Padi Sawah Dengan Menggunakan Model Pendugaan Shierary Rice V.2.1 di tiga lokasi penelitian.

\begin{tabular}{llr}
\hline No & \multicolumn{1}{c}{ Desa } & $\begin{array}{c}\text { Potensi Hasil } \\
(\text { ton ha }\end{array}$ \\
\hline 1. & Popontolen & 6,11 \\
2. & Pakuweru & 5,73 \\
3. & Karowa & 9,00 \\
& Rata-rata & 6,95 \\
\hline
\end{tabular}

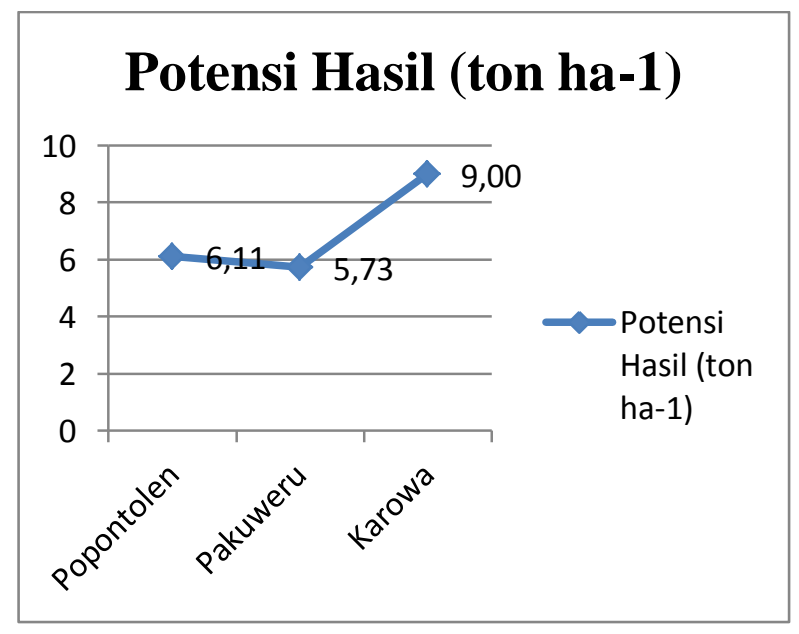

Gambar 1. Data Potensi Hasil Padi Sawah Dengan Menggunakan Model Pendugaan Shierary Rice V.2.1 di tiga lokasi penelitian. pada tiga sampel lokasi penelitian tidak berpengaruh terhadap potensi hasil tertinggi yang didapat. Potensi hasil tertinggi di Desa Karowa Kecamatan Tompaso Baru dengan 9 Ton $\mathrm{Ha}^{-1}$, memiliki radiasi matahari terendah yaitu 22,66 $\mathrm{MJ} \mathrm{m}^{-2}$ hari $^{-1}$.

Tabel 4. Perbandingan Data Potensi Hasil (Ton $\mathrm{Ha}^{-1}$ ) dengan Data Curah Hujan Rata-rata (mm)

\begin{tabular}{llcc}
\hline No & Desa & $\begin{array}{c}\text { Potensi } \\
\text { Hasil (Ton } \\
\left.\mathrm{Ha}^{-1}\right)\end{array}$ & $\begin{array}{l}\text { Curah } \\
\text { Hujan } \\
(\mathrm{mm})\end{array}$ \\
\hline 1. & Popontolen & 6,11 & 284,08 \\
2. & Pakuweru & 5,73 & 270,57 \\
3. & Karowa & 9,00 & 293,50 \\
\hline
\end{tabular}

Dari Tabel 8 tersebut terlihat bahwa intensitas cahaya matahari (jam) pada tiga sampel lokasi penelitian tidak berpengaruh terhadap potensi hasil tertinggi yang didapat. Potensi hasil tertinggi di Desa Karowa Kecamatan Tompaso Baru dengan 9 Ton $\mathrm{Ha}^{-1}$, memiliki intensitas cahaya matahari terendah yaitu 6,53 jam.

Tabel 5. Perbandingan Data Potensi Hasil (Ton $\mathrm{Ha}^{-1}$ ) dengan Data Suhu Maksimum Rata-rata $\left({ }^{0} \mathrm{C}\right)$

\begin{tabular}{clcc}
\hline No & Desa & $\begin{array}{c}\text { Potensi } \\
\text { Hasil } \\
(\text { Ton } \\
\left.\mathrm{Ha}^{-1}\right)\end{array}$ & $\begin{array}{c}\text { T Max Rata- } \\
\text { rata }\end{array}$ \\
\hline 1. & Popontolen & 6,11 & 27,93 \\
2. & Pakuweru & 5,73 & 28,89 \\
3. & Karowa & 9,00 & 23,12 \\
\hline
\end{tabular}




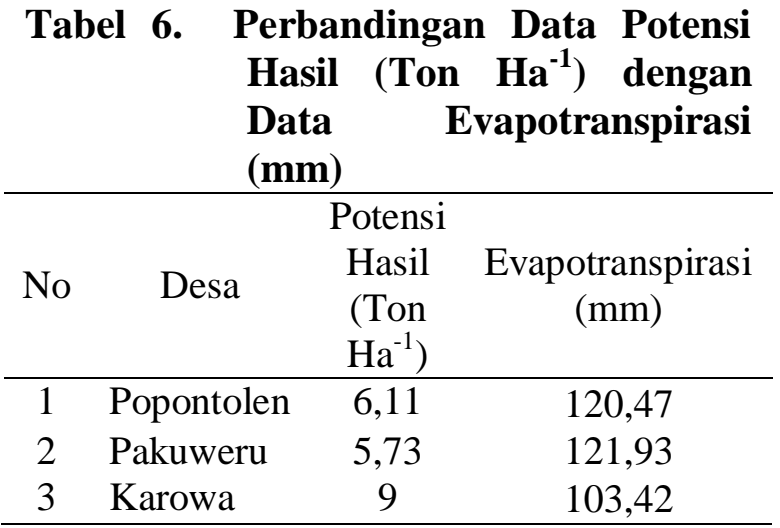

Perbandingan Potensi Hasil Penelitian dengan Data Produktivitas Padi Sawah di Kabupaten Minahasa Selatan.

Perbandingan potensi hasil penelitian di Desa Popontolen Kecamatan Tumpaan, Desa Pakuweru Kecamatan Tenga dan Desa Karowa Kecamatan Tompaso Baru dengan data rill produktivitas rata-rata tahun 2010-2014 komoditi padi sawah Kecamatan Tumpaan, Kecamatan Tenga dan Kecamatan Tompaso Baru dapat dilihat pada Tabel 9.

Tabel 7. Perbandingan Data Potensi Hasil (Ton $\mathrm{Ha}^{-1}$ ) dengan Data Radiasi Rata-rata (MJ $\mathbf{m}^{-2}$ hari $^{-1}$ )

\begin{tabular}{rlrr}
\hline No & Desa & $\begin{array}{r}\text { Potensi Hasil } \\
\left(\text { Ton } \mathrm{Ha}^{-1}\right)\end{array}$ & $\begin{array}{c}\text { Radiasi } \\
\left(\mathrm{MJ} \mathrm{m}^{-2}\right. \\
\left.\text { hari }^{-1}\right)\end{array}$ \\
\hline 1 & Popontolen & 6,11 & 22,78 \\
2 & Pakuweru & 5,73 & 22,80 \\
3 & Karowa & 9 & 22,66 \\
\hline
\end{tabular}

Dari Tabel 15 dan Gambar 13 terlihat bahwa potensi produksi padi sawah hasil penelitian di Desa Popontolen Kecamatan Tumpaan, Desa Pakuweru Kecamatan Tenga dan Desa Karowa Kecamatan Tompaso Baru lebih tinggi dari data produktivitas rata-rata tahun 2010-2014 di Kecamatan Tumpaan, Kecamatan Tenga dan Kecamatan Tompaso Baru. Hal ini disebabkan karena faktor-faktor pendukung produksi yang digunakan dalam penelitian seperti penggunaan benih, pupuk, kecukupan air, jenis varietas diasumsikan dalam keadaan/kondisi yang ideal.

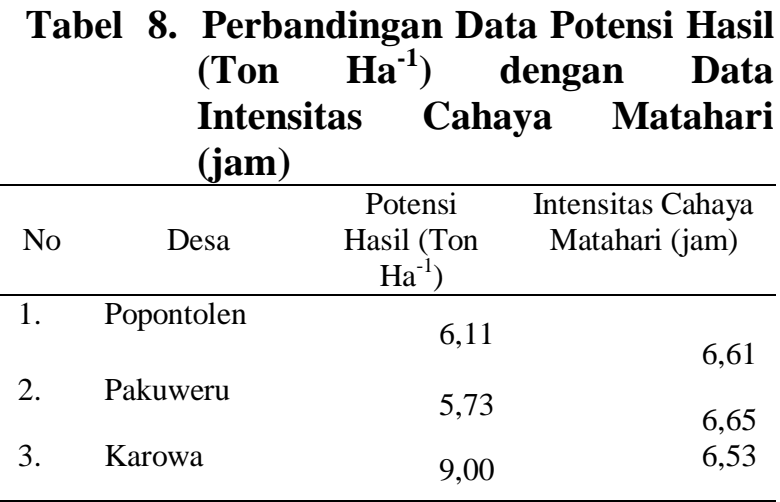

Sementara dari hasil penelitian di lapangan menunjukan bahwa untuk Kecamatan Tompaso Baru, pembudidayaan padi sawah sebagian (40 \%) masih menggunakan benih unggul lokal yaitu varietas sarayu dan super win yang produktivitasnya berkisar antara 4,0-5,2 ton $\mathrm{ha}^{-1}$, sebagian lagi $(60 \%)$ sudah menggunakan varietas unggul nasional yaitu inpari 9 dan cigeulis yang produktivitasnya 6,08,0 ton $\mathrm{ha}^{-1}$. Masih tingginya penggunaan benih unggul lokal disebabkan karena ketersediaan benih unggul nasional yaitu inpari 9 dan cigeulis belum mencukupi karena di Kecamatan Tompaso Baru hanya terdapat satu penangkar benih yaitu Kelompok Tani Suka Maju di desa Tompaso Baru Dua. Irigasi di Kecamatan Tompaso Baru sudah baik karena berdasarkan hasil penelitian di lapangan sawah di tompaso baru sudah beririgasi $1 / 2$ teknis. Walaupun demikian masih ada kerusakan bendungan didaerah-daerah tertentu seperti di daerah irigasi karowa, sehingga ada sekitar $100 \mathrm{Ha}$ lahan sawah yang tidak dapat difungsikan maksimal. Penggunaan pupuk di Kecamatan Tompaso Baru rata-rata menggunakan dosis $150 \mathrm{~kg}$ urea dan $200 \mathrm{~kg}$ NPK walaupun di beberapa periode penanaman, penggunaan pupuk berkurang karena terjadi kelangkaan pupuk bersubsidi akibat terlambatnya penyaluran pupuk bersubsidi dari distributor ke kios-kios saprodi di Kecamatan Tompaso Baru sehingga mengakibatkan hasil panen menurun. Penggunaan alat dan mesin pertanian dalam hal ini penggunaan hand traktor untuk pengolahan lahan, masih mengcover sekitar $70 \%$ luas lahan sawah di kecamatan tompaso baru, masih ada $30 \%$ lahan yang menggunakan tenaga manusia dan hewan. 
Tabel 9. Perbandingan Data Hasil Penelitian Desa Popontolen dengan Data Provitas Padi Sawah di Kecamatan Tumpaan

\begin{tabular}{llcc}
\hline No & \multicolumn{1}{c}{ Lokasi Penelitian } & $\begin{array}{c}\text { Produktivitas } \\
\text { Riil Rata-rata } \\
\text { Tahun 2010- } \\
2014 \\
\left(\mathrm{Ton} \mathrm{Ha}^{-1}\right)\end{array}$ & $\begin{array}{c}\text { Potensi Padi Sawah Hasil Penelitian } \\
\left(\mathrm{Ton} \mathrm{Ha}^{-1}\right)\end{array}$ \\
\hline 1. & $\begin{array}{l}\text { Desa Popontolen } \\
\text { (Kecamatan Tumpaan) }\end{array}$ & 5,27 & 6,11 \\
2. & $\begin{array}{l}\text { Desa Pakuweru } \\
\text { (Kecamatan Tenga) }\end{array}$ & 5,27 & 5,73 \\
3. & $\begin{array}{l}\text { Desa Karowa } \\
\text { (Kecamatan Tompaso Baru }\end{array}$ & 5,29 & 9,00 \\
\hline
\end{tabular}

Hasil penelitian di lapangan untuk Kecamatan Tumpaan didapatkan, penggunaan benih sebagian besar $(60 \%)$ menggunakan benih unggul lokal yaitu verietas serayu, apel dan padi mas, yang menggunakan benih unggul nasional sebesar $40 \%$ yaitu varietas inpari 9 . Sumber benih unggul nasional yaitu varietas inpari 9 berasal dari penangkar benih Kelompok Tani Cahaya Desa Popontolen Kecamatan Tumpaan, sementara untuk sumber benih lokal berasal dari hasil panen kemudian diseleksi lagi untuk dijadikan benih. Masih banyak yang menggunakan benih unggul lokal karena hasil yang didapatkan tidak berbeda jauh dengan menggunakan benih unggul nasioanal yaitu 4,95,6 ton $\mathrm{ha}^{-1}$. Irigasi di Kecamatan Tumpaan sebagian besar sudah merupakan irigasi $1 / 2$ teknis walaupun masih ada lahan sawah seluas 3 ha yang merupakan sawah tadah hujan. Untuk Desa Popontolen ada lahan sawah seluas 20 ha yang walaupun sudah beririgasi $1 / 2$ teknis, tapi kalau musim panas lahan tersebut tidak akan mendapat suplai air yang cukup karena menurunnya debit air irigasi Penggunaan pupuk di Kecamatan Tumpaan rata-rata menggunakan dosis $300 \mathrm{~kg}$ urea dan $150 \mathrm{~kg}$ NPK Phonska walaupun di beberapaperiode penanaman, penggunaan pupuk berkurang karena terjadi kelangkaan pupuk bersubsidi akibat terlambatnya penyaluran pupuk bersubsidi dari distributor ke kios-kios saprodi di Kecamatan Tumpaan sehingga meng-akibatkan hasil panen menurun. Penggunaan alat dan mesin pertanian dalam hal ini penggunaan hand traktor untuk pengolahan lahan, sudah $100 \%$ menggunakan hand traktor. Walaupun sebenarnya kalau terja- di penanaman serentak ada beberapa luasan lahan sawah yang mengalami penundaan tanam karena menunggu hand traktor selesai digunakan di lahan sawah lain.

Hasil penelitian di lapangan untuk Kecamatan Tenga didapatkan, penggunaan benih sebagian besar $(65 \%)$ menggunakan benih unggul nasional yaitu verietas inpari 9 dan IR-64, yang menggunakan benih unggul lokal sebesar $35 \%$ yaitu varietas serayu. Sumber benih unggul nasional yaitu varietas inpari 9 berasal dari penangkar benih Kelompok Tani Cahaya Desa Popontolen Kecamatan Tumpaan, dan untuk varietas IR-64 diambil dari Balai Benih di Kota Tomohon dan telah dikembangkan oleh Kelompok Tani Palm Star di Desa Pakuweru Kecamatan Tenga. Sementara untuk sumber benih lokal berasal dari hasil panen kemudian diseleksi lagi untuk dijadikan benih kembali. Dari hasil penelitian di lapangan menunjukan produktivitas benih unggul nasional yaitu varietas inpari 9 dan IR64 sebesar 5,0-5,3 ton ha $^{-1}$, sementara untuk benih unggul lokal yaitu serayu produktivitasnya sebesar 4,7-5,0 ton ha $^{-1}$. Irigasi di Kecamatan tenga sebagain besar yaitu seluas 616 ha sudah merupakan irigasi $1 / 2$ teknis walaupun masih ada lahan sawah seluas 19 ha merupakan irigasi desa dan 2 ha merupakan sawah tadah hujan. Untuk Desa pakuweru ada lahan sawah seluas 10 ha yang merupakan irigasi desa, kalau musim panas lahan tersebut tidak mendapat suplai air yang cukup karena menurunnya debit air irigasi serta terjadi banyak rembesan pada irigasinya. Penggunaan pupuk di Kecamatan Tenga rata-rata menggunakan dosis 
300-350 kg urea dan $100 \mathrm{~kg}$ NPK walaupun di beberapa periode penanaman, penggunaan pupuk berkurang karena terjadi kelangkaan pupuk bersubsidi akibat terlambatnya penyaluran pupuk bersubsidi dari distributor ke kios-kios saprodi di Kecamatan Tenga sehingga mengakibatkan hasil panen menurun. Penggunaan alat dan mesin pertanian dalam hal ini penggunaan hand traktor untuk pengolahan lahan, sudah 90-100 \% menggunakan hand traktor. Kalau terjadi penanaman serentak ada $10 \%$ luasan lahan sawah yang pengolahan tanahnya menggunakan tenaga manusia.

Dari data potensi hasil penelitian dengan menggunakan model simulasi tanaman Shierary Rice V.2.1 dan dibandingakn dengan data produktivitas riil di lapangan, dapat memberikan masukan/rekomendasi kepada instansi terkait dalam hal ini Dinas Pertanian dan Peternakan Kabupaten Minahasa Selatan untuk dapat mengoptimalkan potensi produksi padi sawah di Kabupaten Minahasa Selatan dengan menyentuh faktor-foktor yang mempengaruhi peningkatan produktivitas padi sawah yaitu : (1). Penyediaan benih unggul dengan memberdayakan penangkar benih agar mampu menyediaan benih unggul bagi petani, karena dari data penelitian dilapangan masih masih banyak petani (35-60 \%) yang menggunakan benih unggul lokal yang bersumber dari seleksi kembali benih dari hasil panen petani. Benih unggul lokal memiliki produktivitas ratarata masih lebih rendah apabila dibandingkan dengan produktivitas benih unggul nasional seperti inpari 9, cigeulis dan IR-64; (2). Menjamin ketersediaan pupuk bersubsidi bagi petani dengan memperkuat Komisi Pengawasan Pupuk dan Pestisida (KP3) serta Tim Verifikasi dan Validasi Penyaluran Pupuk Bersubsidi tingkat Kecamatan dan Kabupaten. Hasil penelitian di lapangan ada waktu-waktu teretentu terjadi kelangkaan pupuk di lapangan, menyebabkan petani mengurangi dosis penggunaan pupuk sehingga produktivitas yang dihasilkan menjadi menurun; (3). Memperbaiki infrastruktur irigasi, karena masih terdapat lahan sawah tadah hujan, dan lahan sawah irigasi desa yang apabila di musim kemarau mengakibatkan debit air menurun sehingga tidak mampu mengairi lahan-lahan tersebut; (4). Penggunaan alat dan mesin pertanian dengan menyalurkan bantuan alat dan mesin pertanian dalam hal ini hand traktor yang tepat sasaran. Data hasil penelitian di lapangan menunjukan masih ada lahan seluas 10-30\%, pengolahan tanahnya masih menggunakan tenaga manusia.

Dengan menyentuh faktor-faktor tersebut, produktivitas padi sawah yang akan dihasilkan diharapkan akan mendekati ataupun menyamai dengan potensi hasil produksi menggunakan model simulasi tanaman Shierary Rice V.2.1. Hal ini sangat dimukinkan karena Kabupaten Minahasa Selatan memiliki iklim yang sangat cocok untuk pertumbuhan dan perkembangan padi sawah serta didukung dengan ketersediaan sumber-sumber air yang optimal.

Dalam mewujudkan salah satu agenda prioritas Nawacita berupa pencapaian Kedaulatan Pangan, adalah dengan peningkatan produktivitas dan produksi padi sawah, sehingga dapat mencukupi kebutuhan beras masyarakat. Dalam menghitung ketersediaan dan konsumsi beras di Kabupaten Minahasa Selatan terlebih dahulu akan dibandingkan data potensi produksi padi sawah rata-rata dengan menggunakan model simulasi tanaman Shierary Rice V.2.1 dengan produktivitas padi sawah tahun 2014 seperti terlihat pada Tabel 10 .

Tabel 10. Perbandingan Data Potensi Produksi Hasil Penelitian dengan Data Produktivitas Padi Sawah di Kabupaten Minahasa Selatan Tahun 2014.

\begin{tabular}{|c|c|c|c|}
\hline No & Tahun & $\begin{array}{l}\text { Provitas } \\
\text { Kabupaten } \\
\left(\text { Ton } \mathrm{Ha}^{-1}\right)\end{array}$ & $\begin{array}{c}\text { Provitas rata- } \\
\text { rata Hasil } \\
\text { Penelitian } \\
\left(\text { Ton } \mathrm{Ha}^{-1}\right) \\
\end{array}$ \\
\hline 1. & 2014 & 5,34 & 6,95 \\
\hline
\end{tabular}

Berdasarkan perhitungan dari Badan Ketahanan Pangan Kabupaten Minahasa Selatan dalam buku Analisis Konsumsi Pangan Tahun 2014 data Padi Sawah yaitu Luas Panen 12.884 ha, Produktivitas 5,34 ton $\mathrm{ha}^{-1}$ maka produksi sebesar 68.740 ton Gabah Kering Panen (GKP) dan jumlah produksi Padi Ladang sebesar 5.451 ton Gabah Kering Panen (GKP), maka total produksi Padi keseluruhan sebesar 74.191 ton Gabah Kering Panen (GKP). Dan dikonversikan ke Gabah Kering Giling (GKG) menjadi 
60.836.62 ton Gabah Kering Giling (82\% dari 74.191 ton Gabah Kering Panen) kemudian dikonversikan ke Beras menjadi 43.030 ton (70,73\% dari 74.191 ton Gabah Kering Giling atau $58 \%$ dari 74.191 ton Gabah Kering Panan) maka jumlah ketersediaan Beras sebesar 40.878,5 ton (5\% penyusutan dari 43.030 ton Beras). Selanjutnya berdasarkan data dari Bagian Bagian Administrasi Pemerintahan Umum Sekretariat Daerah Kabupaten Minahasa Selatan yang tertuang dalam Laporan Penyelenggaraan Pemerintahan Daerah (LPPD) Tahun 2014, dengan jumlah penduduk Kabupaten Minahasa Selatan sebanyak 241.862 jiwa dengan konsumsi / kapita / orang / tahun sebesar 129,283 kg. Maka kebutuhan Beras di Kabupaten Minahasa Selatan Tahun 2014 sebesar 31.268,64 ton. Dengan demikian Kabupaten Minahasa Selatan Tahun 2014 Surplus Beras sebesar 9.609,86 ton Beras.

Apabila dalam perhitungan Analisis Konsumsi Pangan menggunakan data potensi produksi hasil penelitian rata-rata sebesar 6,95 ton $\mathrm{ha}^{-1}$, dengan luas panen padi sawah 12.884 ha didapat produksi sebesar 89.554 ton Gabah Kering Panen (GKP) dan jumlah produksi Padi Ladang sebesar 5.451 ton Gabah Kering Panen (GKP), maka total produksi Padi keseluruhan sebesar 94.995 ton Gabah Kering Panen (GKP), setelah dikonversi ke beras menjadi 52.342 ton. Dengan jumlah konsumsi beras penduduk Kabupaten Minahasa Selatan Tahun 2014 sebesar 31.268,64 ton, maka terjadi surplus beras di Kabupaten Minahasa Selatan sebanyak 21.073 ton. Dengan menggunakan data potensi produksi hasil penelitian terjadi peningkatan surplus beras sebesar $119 \%$ dibandingkan dengan data riil kabupaten.

Berikut ini ditampilkan pemetaan potensi produksi padi sawah di Kabupaten Minahasa Selatan dengan menggunakan Foto Citra Satelit dan diolah melalui aplikasi Arcview 3.3, dengan mengambil tiga sampel penelitian yang mewakili tujuh kecamatan dengan potensi lahan sawah terbesar yaitu sampel ke satu Desa Popontolen Kecamatan Tumpaan mewakili potensi sawah Kecamatan Tumpaan dan Tatapaan, sampel ke dua Desa Pakuweru Kecamatan Tenga mewakili potensi sawah Kecamatan Tenga dan Sinonsayang dan sampel ke tiga Desa Karowa Kecamatan Tompaso Baru mewakili potensi lahan sawah Kecamatan Ranoyapo, Tompaso Baru dan Maesaan.
Gambar 3. Pemetaan Potensi Produksi Padi Sawah di Desa Popontolen

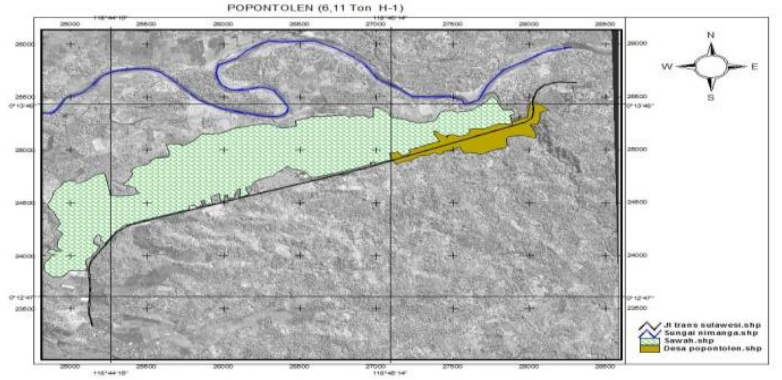

Gambar 4. Pemetaan Potensi Produksi Padi Sawah di Desa Pakuweru

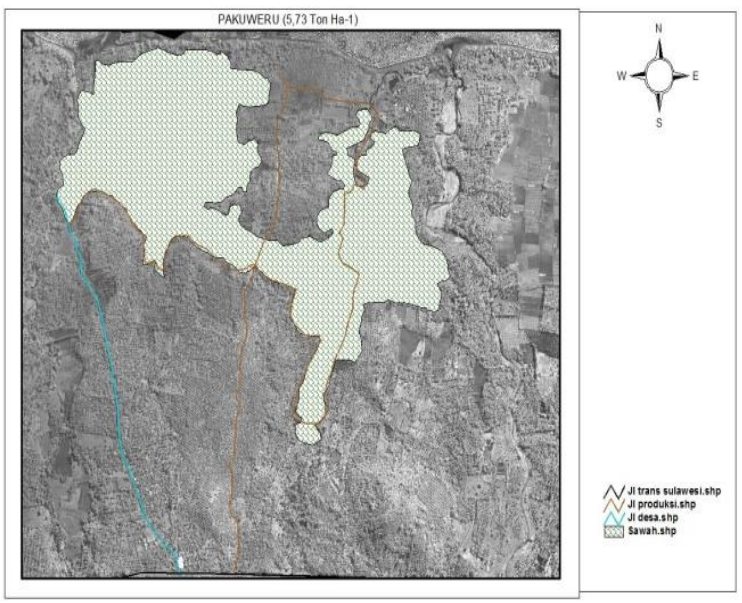

Gambar 5. Pemetaan Potensi Produksi Padi Sawah di Desa Karowa

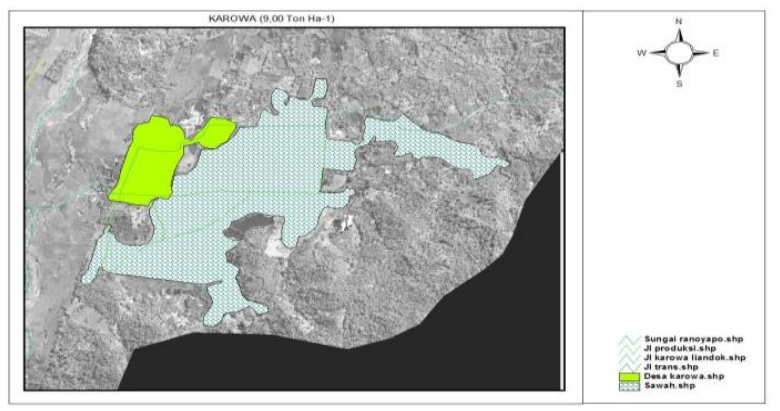

\section{KESIMPULAN DAN SARAN}

\section{Kesimpulan}

Berdasarkan hasil penelitian, maka disimpulkan bahwa :

1. Potensi hasil produksi padi sawah hasil penelitian yaitu Desa Popontolen 6,11 ton $\mathrm{ha}^{-1}$, Desa Pakuweru 5,73 ton ha ${ }^{-1}$, dan Desa 
Karowa 9,00 ton $\mathrm{ha}^{-1}$, potensi produksi tertinggi berada pada lokasi penelitian Desa Karowa yaitu 9,00 ton ha $^{-1}$ disebabkan memiliki suhu yang paling ideal untuk pertumbuhan dan perkembangan padi sawah yaitu rata-rata $23,12{ }^{\circ} \mathrm{C}$, serta curah hujan rata-rata $293,50 \mathrm{~mm}$ dan evapotranspirasi $103,42 \mathrm{~mm}$.

2. Peta yang dihasilkan ditujukan kepada instani terkait Dinas Pertanian dan Peternakan Kabupaten Minahasa Selatan sebagai bahan pertimbangan dalam perencanaan pengembangan padi sawah kedepan.

\section{Saran}

Adapun saran dalam penelitian ini :

1. Kondisi agroklimat Kabupaten Minahasa Selatan yang sangat cocok dalam pengembangan padi sawah, dapat mendukung perwujudan kedaulatan pangan di Provinsi Sulawesi Utara.

2. Hasil penelitian ini sebagai masukan pada instansi terkait dalam hal ini Dinas Pertanian dan Peternakan Kabupaten Minahasa Selatan dalam mengoptimalkan produksi padi sawah dengan kegiatan menyentuh faktor-faktor pendukung produksi seperti penyediaan benih unggul, penggunaan pupuk yang berimbang, perbaikan bendungan dan jaringan irigasi serta penggunaan alat dan mesin pertanian sehingga dapat meningkatkan pendapatan petani.

\section{Daftar Pustaka}

Badan Ketahanan Pangan Kabupaten Minahasa Selatan, Analisis Konsumsi Pangan, Badan, 2015

Anonim, 1990. Budidaya Tanaman Padi, Kanisius Yogya.

Bey, A. 1991. Metode Kausal dan Time Series untuk Analisis Data Iklim. Kapita Selekta dalam Agrometeorologi. Direktorat Jenderal Pendidikan Tinggi. Depdikbud, Jakarta.
Budiyanto, E. 2005. Sistem Informasi Geografis Menggunakan ArcView. Penerbit ANDI. Yogyakarta.

Daradjat, A.A., Setyono, A., Makarim, A.K., dan Hasanudin, A. 2009. Padi : Inovasi Teknologi Produksi. LIPI Press. Jakarta

Handoko, I. 1996. Analisis Sistem dan Model Stimulasi Komputer untuk Perencanaan Pertanian di Indonesia. Materi Pelatihan. Jurusan Geofisika dan Meteorology. FMIPA. IPB Bogor. $112 \mathrm{p}$.

Hardjono R. Soemartono dan Bahrin S. 1981.Bercocok Tanam Padi, Yasaguna, Jakarta.

Khudori, 2002. Menyiasati Defisit Ketersediaan Beras. Surya Online, Jakarta.

Dinas Pertanian dan Peternakan Kabupaten Minahasa Selatan, Laporan Tahunan Dinas Pertanian dan Peternakan, 2014.

Lakitan, Benyamin. Dasar-Dasar Klimatologi. 1994. Jakarta: Raja Grafindo Persada.

Peng, S. et al. 1994. Quantitative Understanding of Yield Potencial. In Cassman, K.G. (Ed). Breaking the Yield Barrier. Proc. Workshop on Rice Yield Potencial in Favorable Environments.p. 5-20.

Kementerian Pertanian RI Rencana Strategis Kementrian Pertanian RI Tahun 2014-2019, 2014

Dinas Pertanian dan Peternakan Kabupaten Minahasa Selatan, Rencana Strategis 2010-2015, 2011

Rogi, J, E, X 2002. Penyusunan Model Simulasi Dinamika Nitrogen Pertanaman Kelapa Sawit (Elaels guineensis Jacg.) Di Unit Usaha Bekri Provinsi Lampung. Disertasi PPS IPB Bogor

Sugiarto, Y. 2002., Geografi Modeling dan Analisis. FMIPA IPB Bogor.

Wirjohamidjojo S dan Y. S. Swarinoto. 2010. Iklim Kawasan Indonesia. Pusat 